\title{
PROFIL NYERI DAN PERUBAHAN HEMODINAMIK PASCA BEDAH PERUT BAWAH DENGAN KETOROLAK 30 mg INTRAVENA
}

\author{
${ }^{1}$ Kiki Ekawati \\ ${ }^{2}$ Diana Lalenoh \\ ${ }^{2}$ Lucky Kumaat \\ ${ }^{1}$ Kandidat Skripsi Fakultas Kedokteran Universitas Sam Ratulangi Manado \\ ${ }^{2}$ Bagian Anestesiologi dan Terapi Intensif Fakultas Kedokteran \\ Universitas Sam Ratulangi Manado \\ Email: kiki.ekawati@ymail.com
}

\begin{abstract}
Abstrak: Nyeri sebagai suatu pengalaman sensorik dan emosional yang tidak menyenangkan, berkaitan dengan kerusakan jaringan yang nyata atau yang berpotensial menimbulkan kerusakan jaringan. Tujuan penelitian ini adalah untuk mengetahui profil nyeri dan perubahan hemodinamik seperti tekanan darah, nadi dan laju napas pada pasien bedah perut bawah dengan analgetik ketorolak $30 \mathrm{mg}$ intravena. Profil nyeri dinilai dengan menggunakan Visual Analog Scale (VAS). Penelitian ini menggunakan pendekatan deskriptif retrospektif dan dilakukan di ruang pemulihan recovery room (RR) pasca bedah dan di Instalasi Rawat Inap A dan D RSUP Prof. Dr. R.D Kandou Manado pada bulan November 2014 - Desember 2014. Sampel adalah 20 kasus yang dilakukan operasi bedah perut bawah yang memenuhi kriteria inklusi. Hasil penelitian menunjukkan bahwa rata-rata skor VAS pada jam ke-0 dan ke-2 adalah 0 sedangkan rata-rata skor VAS pada jam ke-4 dan jam ke-6 adalah 1,65 dan 6,80 secara berurutan. Rata-rata tekanan darah pada jam ke-0 adalah 110/75, jam ke-2 adalah 119/75, jam ke-4 adalah 120/80 dan jam ke-6 menjadi 122/83 mmHg. Rata-rata laju nadi jam ke-0 adalah 80,1, jam ke-2 adalah 80,3, jam ke-4 adalah 80,25 dan jam ke-6 menjadi 80,80 denyut per menit. Rata-rata laju napas pada jam ke-0 adalah 21,25, jam ke-2 adalah 20,45, jam ke-4 adalah 20,15 dan jam ke-6 menjadi 21,30x/menit.
\end{abstract}

Kata kunci: visual analog scale, perubahan hemodinamik, ketorolak

\begin{abstract}
Pain as a sensory and emotional experience unpleasant, related with actual tissue damage or potential tissue damage. The purpose of this study is to determine the profile of pain and hemodynamic changes such as blood pressure, pulse and respiratory rate in patients of lower abdomen surgical with the analgesic ketorolac $30 \mathrm{mg}$ intravenously. The profile of pain was valued by Visual Analog Scale (VAS). This study used prospective descriptive approach and was conducted at recovery room (RR) after surgery and also at Inpatient installation A and D RSUP Prof. Dr RD Kandou Manado on November 2014 - December 2014. Samples were 20 cases of lower abdominal surgery which fulfilled the inclusion criterias. This study found that the average of VAS score on 0 hour and 2nd hour are 0 while average of VAS score on the 4th and 6th hour are 1,65 and 6,80 respectively. Average of blood pressures on 0 hour is $110 / 75$, the 2nd hour is $119 / 75$, 4th hour is $120 / 80$ and 6th hour is become $122 / 83 \mathrm{mmHg}$. Average pulse rate on 0 hour is 80.1 , 2nd hour is 80.3 , 4th hour is 80.25 and 6th hour is become 80.80 pulse per minute. The average respiratory rate on 0 hour is 21.25 , 2nd hour is 20.45 , 4th hour is 20.15 and 6th hours is become $21.30 \mathrm{x} /$ minute.
\end{abstract}

Keywords: visual analog scale, hemodynamic changes, ketorolac 
Pada setiap pembedahan, diperlukan upaya untuk menghilangkan nyeri. Thomas Morton pada tahun 1846 menemukan bahwa inhalasi gas eter dapat menimbulkan analgesia selama pembedahan gigi. Sejak saat itu anestesiologi berkembang pesat. Pada saat ini, bidang anestesiologi tidak saja meliputi pengelolaan nyeri dan fungsi vital selama pembedahan, tetapi juga dalam hal pengelolaan perioperatif untuk mendukung keberhasilan pembedahan. ${ }^{1}$

Pada tahun 1979, International Association for the Study of Pain mendefinisikan nyeri sebagai "suatu pengalaman sensorik dan emosional yang tidak menyenangkan, yang berkaitan dengan kerusakan jaringan yang nyata atau yang berpotensial menimbulkan kerusakan jaringan”. Nyeri timbul akibat adanya rangsangan oleh zat-zat algesik pada reseptor nyeri yang banyak dijumpai pada lapisan superfisial kulit dan beberapa jaringan di dalam tubuh, seperti periosteum, permukaan sendi, otot rangka dan pulpa gigi. Reseptor nyeri merupakan ujung-ujung bebas serat saraf aferen A delta dan C. reseptor-reseptor ini diaktifkan oleh adanya rangsangan-rangsangan dengan intensitas tinggi, misalnya berupa rangsangan termal, mekanik, elektrik atau rangsangan kimiawi. ${ }^{2}$

Pencegahan nyeri direncanakan sebelum operasi agar penderita tidak terganggu oleh nyeri setelah pembedahan. ${ }^{1}$ Pasien pada nyeri akut memperlihatkan respon neurologik yang terukur yang disebkan oleh stimulasi simpatis yang disebut sebagai hiperaktivitas autonom. Perubahan-perubahan ini mencakup takikardia, takipnea, meningkatnya aliran darah perifer, meningkatnya tekanan darah (baik sistol maupun diastolik), dan dibebaskannya katekolamin-suatu respon stres yang khas (Fields, Martin, 2001). ${ }^{3}$ Analgetik sebaiknya diberikan sebelum nyeri timbul dengan dosis memadai. Jenis obat dan cara pemberiannya bergantung pada penyebab dan letak nyeri, dan keadaan penderita. ${ }^{1}$

Non Steroidal Anti-inflammatory Drugs (NSAID)telah terbukti efektif dalam pengobatan nyeri pasca operasi. Selain itu, golongan non opioid dan secara signifikan dapat mengurangi kejadian efek samping opioid terkait seperti mual dan muntah pasca operasi dan sedasi. NSAID parenteral seperti ketorolac biasanya digunakan sebagai bagian dari pendekatan multimodal untuk manajemen nyeri pasca operatif akut. Ketorolak merupakan satu dari sedikit NSAID yang tersedia untuk pemberian parenteral. ${ }^{4}$ Absorbsi oral dan intramuskular berlangsung cepat mencapai puncak dalam 30-50 menit. Dosis intramukular 30-60 mg; IV 15-30 mg dan oral 5-30 mg. ${ }^{5}$ Seperti NSAID lainnya, ketorolac menghambat agregasi platelet dan memperpanjang waktu perdarahan. Ketorolak dan NSAID lainnya oleh karenanya harus digunakan dengan hatihati pada pasien dengan risiko perdarahan pasca operasi. Pemberian jangka panjang dapat menyebabkan toksisitas ginjal (misalnya, nekrosis papiler) atau ulkus saluran pencernaan dengan perdarahan dan perforasi. $^{4}$

Pada penelitian sebelumnya yang dilakukan oleh Meriwijanti, menunjukkan bahwa ketorolak $30 \mathrm{mg}$ IV memiliki efektifitas analgesik lebih baik dibanding dengan ketoprofen $100 \mathrm{mg}$ IV dalam mengatasi nyeri pasca tonsilektomi. ${ }^{6}$

Berdasarkan teori yang telah dijelaskan di atas dan penelitian sebelumnya, maka penulis tertarik untuk meneliti profil nyeri dan perubahan hemodinamik (tekanan darah, nadi, dan pernapasan) pada pasien pasca bedah perut bawah dengan ketorolak $30 \mathrm{mg}$ intravena.

\section{METODE PENELITIAN}

Penelitian ini bersifat deskriptif prospektif yang dilakukan dilakukan di ruang pemulihan recovery room (RR) pasca bedah, Instalasi Rawat Inap A (IRINA A) dan Instalasi Rawat Inap D (IRINA D) di RSUP Prof. Dr. R.D Kandou Manado pada bulan November 2014 sampai Desember 2014. Sampel penelitian adalah pasien pasca bedah perut bawah yang memenuhu kriteria inklusi dan telah menandatangani lembar surat persetujuan (informed 
consent)untuk ikut dalam penelitian. Adapun kriteria inklusi dari penelitian yaitu usia dalam rentang 16-55 tahun, semua jenis bedah perut bawah, misalnya: herniatomi, appendektomi, cystotomi dan kistektomi. ASA I-III. Kriteria eksklusi dari penelitian ini dalah alergi ketorolak, pasien kelainan ginjal, pasien kelainan pembekuan darah, pasien yang memiliki riwayat ulkus saluran pencernaan dan pasien yang tidak menyetujui informed consent. Pengambilan sampel penelitia dilakukan dengan metode purposive samplingyaitu kelompok populasi dipilih berdasarkan kemauan peneliti bahwa individu tersebut adalah sesuai dan cocok untuk dijadikan sampel penelitian. Variabel bebas penelitian ini adalah ketorolak $30 \mathrm{mg}$ intravena, variabel terikanya adalah skor nyeri VAS ( Visual Analog Scale) dan perubahan hemodinamik ( tekanan darah, nadi dan laju napas).

Teknik pengumpulan data pada penelitian awalnya dilakukan wawancara sebelum dilakukan operasi untuk mendapatkan persetujuan atau informed consent dari pasien. Jika pasien telah menyetujui ingin menjadi sampel penelitian, setelah operasi dan pasien telah diberikan analgetik ketorolak $30 \mathrm{mg}$ intravena peneliti menilai nyeri pada jam ke-0, 2, 4 dan 6 menggunakan skor VAS (Visual Analog Scale). Setelah menilai nyeri dalam observasi perubahan hemodinamik pasca bedah dilakukan pengukuran tekanan darah, nadi dan laju napas menggunakan alat stetoskop dan sfigmomanometer digital.

\section{HASIL PENELITIAN}

Dengan data yang telah dikumpulkan peneliti dari bulan November - Desember 2014 berjumlah 20 sampel, hasil penelitian yang akan disajikan dalam bagian ini adalah menyangkut tentang distribusi jenis kelamin, usia, pekerjaan, jenis operasi, VAS, tekanan darah, nadi dan laju napas masing-masing dengan periode jam ke $0,2,4,6$.
Tabel 1 menunjukkan bahwa sebagian besar responden adalah berjenis kelamin perempuan dengan jumlah 19 responden (95\%).

Tabel 1. Distribusi menurut Jenis Kelamin Responden

\begin{tabular}{ccc}
\hline Jenis Kelamin & n & $\mathbf{\%}$ \\
\hline Laki-laki & 1 & 5 \\
Perempuan & 19 & 95 \\
\hline
\end{tabular}

Tabel 2 menunjukkan bahwa sebagian besar responden berusia 35-45 tahun dengan jumlah 8 responden (40\%).

Tabel 2. Distribusi menurut Usia Responden

\begin{tabular}{ccc}
\hline $\begin{array}{c}\text { Usia } \\
\text { (tahun) }\end{array}$ & $\mathbf{n}$ & $\mathbf{\%}$ \\
\hline $16-25$ & 5 & 25 \\
$26-35$ & 2 & 10 \\
$35-45$ & 8 & 40 \\
$46-55$ & 5 & 25 \\
\hline
\end{tabular}

Tabel 3 menunjukkan bahwa sebagian besar responden mempunyai pekerjaan sebagai swasta dengan jumlah responden dengan jumlah 9 responden (45\%).

Tabel 3. Distribusi menurut Pekerjaan Responden

\begin{tabular}{cll}
\hline Pekerjaan & n & \% \\
\hline PNS & 5 & 25 \\
Swasta & 9 & 45 \\
Tidak Bekerja & 6 & 30 \\
\hline
\end{tabular}

Tabel 4. Distribusi menurut Jenis Operasi Yang Dilakukan

\begin{tabular}{ccc}
\hline Jenis Operasi & n & \% \\
\hline Appendektomi & 1 & 5 \\
Histerektomi Radikal & 3 & 15 \\
Histerektomi Totalis & 2 & 10 \\
HTSO & 1 & 5 \\
HTSOB+Adenomiotisis & 1 & 5 \\
Laparatomi VC & 7 & 35 \\
Miomektomi & 1 & 5 \\
RE-Laparatoomi+ Pasang & 1 & 5 \\
DJ Stand & & \\
SO/Kistektektomi & 2 & 10 \\
TVH+KA+KPR & 1 & 5 \\
\hline
\end{tabular}


Tabel 4 menunjukkan bahwa sebagian besar responden mengalami operasi laparatomi VC dengan jumlah 7 responden (35\%).

Tabel 5 menunjukkan bahwa sebagian responden mengalami ASA II dengan jumlah 16 responden (80\%)

Tabel 5. Distribusi menurut ASA Responden

\begin{tabular}{ccc}
\hline ASA & $\mathrm{n}$ & $\%$ \\
\hline I & 4 & 20 \\
II & 16 & 80 \\
\hline
\end{tabular}

Gambar 1 menunjukkan rata-rata nilai skor VAS pada jam ke-0 dan ke-2 adalah 0 tetapi pada jam ke-4 meningkat menjadi 1,65 dan jam ke-6 menjadi 6,8

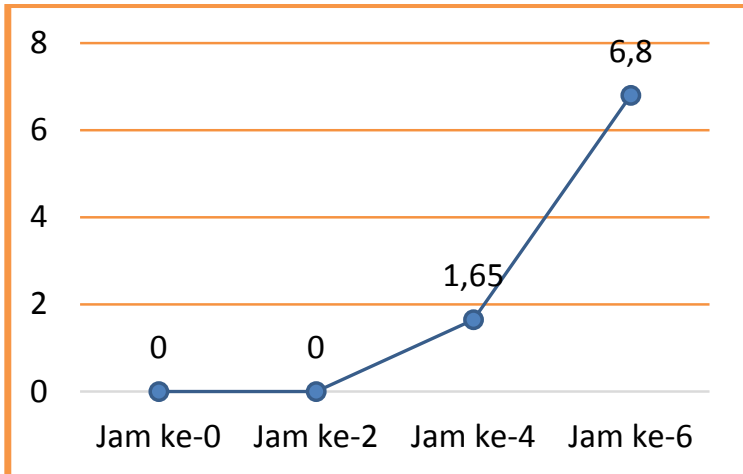

Gambar 1. Rata-rata perkembangan skor VAS pada jam ke-0, 2, 4 dan 6

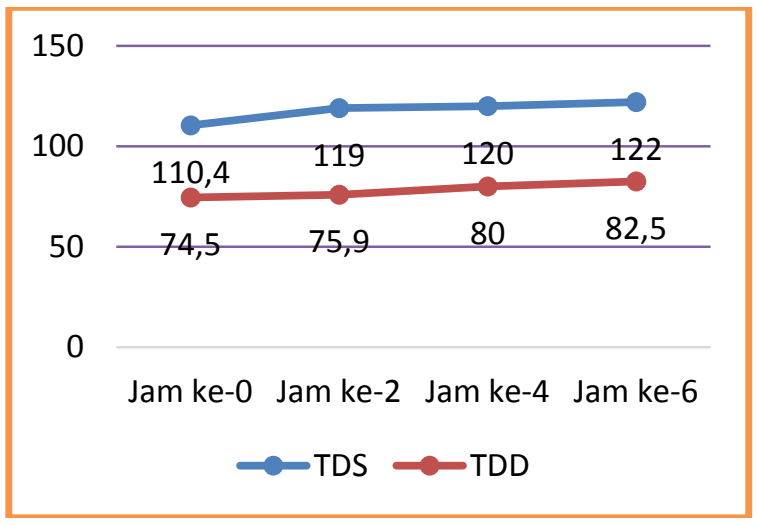

Gambar 2. Rata-rata Tekanan Darah Sistol dan Tekanan Darah Diastol pada jam ke-0, 2, 4 dan 6

Gambar 2 menunjukkan rata-rata nilai tekanan darah jam ke-0 adalah 110/75, meningkat pada jam ke-2 menjadi 119/75, pada jam ke-4 meningkat menjadi 120/80 dan jam ke-6 menjadi 122/83

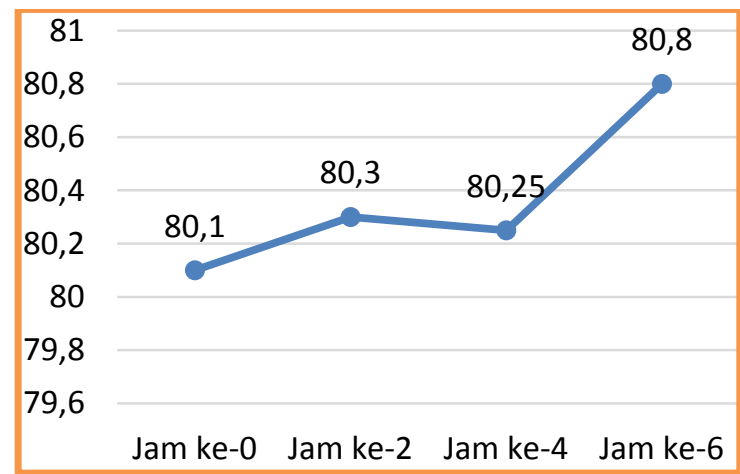

Gambar 3. Rata-rata perkembangan nadi pada jam ke-0, 2, 4 dan 6

Gambar 3 menunjukkan perkembangan nadi jam ke-0 adalah 80,1, jam ke-2 menjadi 80,3 kemudian pada jam ke-4 menjadi 80,25 dan jam ke-6 menjadi 80,8

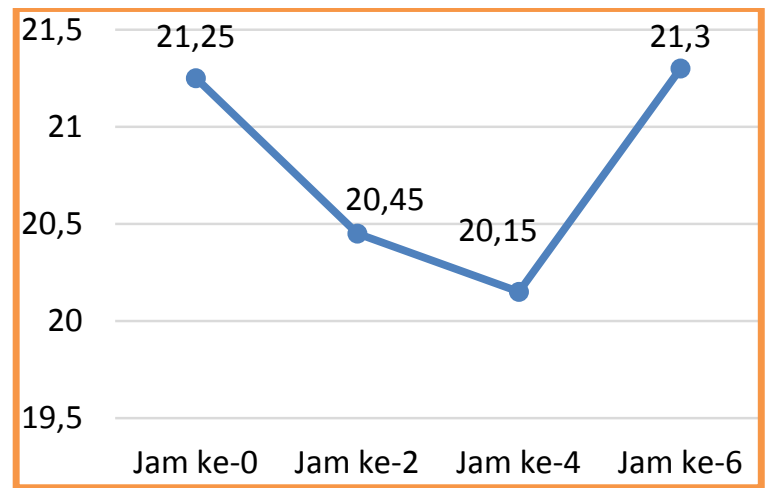

Gambar 4. Rata-rata perkembangan laju napas pada jam ke-0, 2, 4 dan 6

Gambar 4 menunjukkan laju napas jam ke-0 adalah 21,25 kemudian pada jam ke-2 menjadi 20,45, pada jam ke-4 menjadi 20,15 dan jam ke-6 menjadi 21,3

\section{BAHASAN}

Berdasarkan data yang diperoleh dari ruang OK, IRINA A dan IRINA D RSUP Prof. Dr. R.D Kandou Manado, didapati jumlah sampel penelitian sejumlah 20 sampel. Penelitian dan pengambilan sampel dilakukan pada bulan November Desember 2014. Dari sampel tersebut, karakteristik jenis kelamin diperoleh bahwa sebagian besar responden adalah perempuan dengan jumlah 19 responden 
(95\%). Kasus ini berkaitan dengan proses operasi yang sebagian besar adalah laparatomi VC.

Nyeri adalah suatu pengalaman sensorik dan emosional yang tidak menyenangkan, yang berkaitan dengan kerusakan jaringan yang nyata atau yang berpotensial menimbulkan kerusakan jaringan. $^{2}$ Alat bantu yang paling sering digunakan untuk menilai intensitas atau keparahan nyeri pasien adalah visual analog scale (VAS), yang terdiri dari sebuah garis horizontal yang dibagi secara rata menjadi 10 segmen dengan no 0 sampai $10 .^{3}$

Berdasarkan data tentang distribusi frekuensi pada skor VAS diperoleh data bahwa skor VAS pada jam ke-0, seluruh responden penelitian tidak merasakan nyeri apa-apa, demikian juga sampai jam ke-2, seluruh responden tidak merasakan nyeri karena skala nyeri masih berkisar pada angka nol. Namun perubahan mulai terjadi pada jam ke-4, dimana ada sejumlah pasien pasca bedah yang merasakan nyeri pada tahap ini dengan skor VAS yang berbeda yaitu 2, 3, 5 dan 6 yang bisa dikategorikan sampai pada tahap nyeri sedang. Bahkan sampai jam ke-6, skor VAS yang diperoleh sudah tidak ada responden yang tidak merasakan nyeri. Dalam tahap ini sebagian besar pasien sudah merasakan tingkatan nyeri sedang sampai berat sekali.

Untuk mengatasi nyeri pasca bedah seringkali harus diberikan obat analgesik, utamanya golongan NSAID. ${ }^{7}$ Ketorolak adalah obat parenteral antiinflamasi nonsteroid (NSAID) yang menyediakan analgesia dengan menghambat sintesis prostaglandin. Ketorolak, obat yang beraksi secara perifer, telah menjadi alternatif yang populer terhadap opioid untuk analgesia pasca operasi karena efek samping sistem saraf pusat yang minimal. ${ }^{8}$

Schwenzer KJ dkk tahun 1997 didapatkan hasil bahwa pemberian ketorolak $30 \mathrm{mg}$ intravena tidak berpengaruh terhadap tekanan sistolik dan diastolik. $^{9}$ Meriwijanti pada tahun 2001 membandingkan obat analgetik ketoprofen $100 \mathrm{mg}$ intravena dengan ketorolak $30 \mathrm{mg}$ intravena pasca bedah tonsilektomi. Pada penelitian Meriwijanti ditemukan bahwa pada kelompok ketorolak terlihat nilai ratarata skor VAS, tekanan darah sistol maupun diastol, nadi dan laju napas terdapat peningkatan dari menit awal pasca bedah sampai jam ke-12, tetapi masih dalam keadaan normal. Dalam penelitiannya obat analgetik ketorolak 30 mg intravena lebih memiliki efektifitas analgesi dibandingkan dengan ketoprofen $100 \mathrm{mg}$ intravena. ${ }^{6}$

Pada penelitian yang dilakukan oleh peneliti, pemeriksaan tekanan darah pasca bedah masih dalam keadaan normal, dimana diperoleh pada jam ke-0 nilai mean sistolik adalah $110 \mathrm{mmHg}$ dan diastolik 75 mmHg, meningkat pada jam ke-2, 4 dan pada jam ke-6 mencapai puncak mean sistolik menjadi $122 \mathrm{mmHg}$ dan diastolik 83 mmHg. Pada tekanan arteri rerata diperoleh jam ke-0 adalah 86,46, meningkat pada jam ke-2, 4 dan mencapai puncak pada jam ke-6 meningkat menjadi 95, hasil ini sejalan dengan penelitian yang dilakukan oleh KJ dkk tahun 1997 bahwa ketorolak $30 \mathrm{mg}$ intravena tidak berpengaruh terhadap tekanan darah sistolik dan diastolik. ${ }^{9}$ Pada pemeriksaan nadi diperoleh data bahwa terjadi peningkatan nadi setelah beberapa jam pasca operasi. Nadi minimum pada saat jam ke-0 adalah $72 \mathrm{x} / \mathrm{m}$ dan pada jam ke-6 meningkat menjadi $80 \mathrm{x} / \mathrm{m}$. Pada distribusi laju nafas diperoleh data pada jam ke-0 laju nafas minimum adalah 18 meningkat menjadi 80 pada jam ke-2, ke-4 dan ke-6. Sedangkan laju nafas maksimum adalah 24 sampai jam ke-6. Hasil penelitian ini sama dengan yang dilakukan oleh Meriwijanti tahun 2001. Persamaan hasil ini karena berkaitan dengan farmakodinamik ketorolak terhadap sistem kardiovaskuler, karena ketorolak memang tidak menyebabkan perubahan yang bermakna pada parameter tekanan darah dan hemodinamik serta tidak menyebabkan depresi pernapasan. Pada sistem pencernaan, ketorolak $30 \mathrm{mg}$ menyebabkan mual dan muntah yang lebih jarang dibanding dengan morfin $10 \mathrm{mg}$ dan 
$12 \mathrm{mg}$, dapat menyebabkan iritasi lambung, perdarahan gastrointestinal. ${ }^{10}$

\section{SIMPULAN}

1. Skor VAS meningkat seiring bertambahnya waktu pasca operasi. Skor VAS 0 diperoleh pada semua responden di jam ke-0 dampai jam ke2, meningkat pada jam ke-4 dengan skala nyeri ringan sedang dan pada jam ke-6 sebagian responden sudah merasakan skala nyeri hebat sampai hebat sekali.

2. Pada tekanan darah diperoleh jam ke-0 nilai mean adalah 110/75 mmHg, meningkat pada jam ke-2 menjadi 119/75 mmHg, meningkat pada jam ke-4 menjadi 120/80 mmHg, meningkat pada jam ke-6 menjadi 122/83 mmHg. Pada tekanan arteri rerata diperoleh jam ke-0 adalah 86,46, meningkat pada jam ke-2 menjadi 89,93, meningkat pada jam ke-4 menjadi 93,33, pada jam ke-6 meningkat menjadi 95.

3, Terjadi peningkatan nadi setelah beberapa jam pasca operasi. Nadi minimum pada saat jam ke-0 adalah $72 \mathrm{x} / \mathrm{m}$, sedangkan pada jam ke-2 meningkat menjadi $79 \mathrm{x} / \mathrm{m}$, pada jam ke-4 dan ke-6 meningkat menjadi 80 $\mathrm{x} / \mathrm{m}$.

4. Terjadi peningkatan distribusi laju nafas yaitu diperoleh data pada jam ke0 laju nafas minimum adalah 18 meningkat menjadi 80 pada jam ke-2, ke-4 dan ke-6. Sedangkan laju nafas maksimum adalah 24 sampai jam ke-6.

\section{SARAN}

1. Perlu dilakukan penelitian yang lebih lanjut dengan jumlah sampel yang lebih besar.

2. Perlu dilakukan penelitian yang lebih lanjut menggunakan obat ketorolak dibandingkatn dengan obat analgetik lainnya agar dapat mengetahui lebih dalam tentang efek dan cara kerja dari obat ketorolak.

\section{DAFTAR PUSTAKA}

1. Jong. D, Sjamsuhidajat. R. Buku Ajar Ilmu Bedah. Edisi ke 3. Jakarta: Penerbit Buku Kedokteran EGC; 2012

2. Agus D, Triyanto. Manajemen Nyeri Dalam Suatu Tatanan Tim Medis Multidisiplin. Majalah Kedokteran Atmajaya. 2004; 3: 1-13.

3. Price SA, Wilson LM. Patofisiologi, volume 2, edisi ke-6. Jakarta; penerbit Buku Kedokteran EGC, 2006

4. Morgan GE, Mikhail MS, Murray MJ. Morgan's Clinical Anesthesiology. 4th ed. USA: Appleton \& Lange; 2006

5. Gunawan, Sulistia. Farmakologi dan Terapi. Edisi ke 5. Jakarta: Penerbit Buku FKUI; 2010

6. Meriwijanti. Evaluasi Efek Analgesia Pemakaian Ketoprofen dan Ketorolak Intravena Pasca Tonsilektomi [Skripsi]. Semarang: FK-Universitas Diponegoro. 2001

7. Anan F. The Fenomenon of Pain Management. Ethicon 2000; 38 (1) : 14-8

8. Macres SM, Moore PG, Fishman SM. Acute Pain Management. In: Barash GP, Cullen BF, Stoelting RK, Calahan MK, Stock MC. Clinical Anesthesia. 6th ed. Philadelphia: Lippincott Williams \& Wilkins; 2009

9. Gillis JC, Brogden RN. Ketorolac A Reappraisal of its pharmacodyamic and pharmacokineticpropoerties and therapeutik use in pain management. Drugs 1997, 53: 139-88

10.Ketorolac. Hexapharma Jaya a Kalbe Company. Di akses pada 10 oktober 2014. Available at http://www.hexpharmjaya.com/page/ ketorolac.aspx 